\title{
BIBLIO COUNS
}

Biblio Couns : Jurnal Kajian Konseling dan Pendidikan

Vol. 1, No. 3, November 2018, hlm. 97-104

Tersedia Online dijurnal.umsu.ac.id/index.php/biblio

ISSN 2620-3103 (online)

https://doi.org/10.30596/bibliocouns.v1i3.2246

\section{Efektivitas Layanan Informasi Menggunakan Pendekatan Saintifik Untuk Meningkatkan Keterampilan Bertanya Siswa}

\author{
Ilham Khairi Siregar \\ Guidance and Counseling Study Program, Universitas University of Muhammadiyah Sumatera Utara, \\ Correspondence: Jl. Muchtar Basri No. 3 Medan \\ E-mail: ilhamkhairi@umsu.ac.id, 082170482753
}

\section{Article Info \\ History of Article \\ Accepted Oktober 2018 \\ Approved Oktober 2018 \\ Published November 2018}

\section{Key Word}

Information Services;

Scientific Approach;

Asked Skills.

\begin{tabular}{l}
\hline Abstract \\
\hline The purpose of this research is to look at the effectiveness between \\
information services by using a scientific approach and using the \\
method of lectures to enhance the skills of asked students. Type of \\
research is Quasi Experiment with Pretest-Posttest design Control \\
Group Design. The population of research was the student \\
Madrasah Aliyah Aisyiah, Binjai and SMA Muhammadiyah Binjai, \\
subjects were selected using a Purposive Sampling technique. \\
Instrument research using questionnaires. The data were analyzed \\
using the Wilcoxon Signed Ranks Test and Kolmogorov-Smirnov \\
Two Sample Independent with the help of SPSS version 20.0. \\
Based on the findings, scientific approach to information services \\
more effectively to improve the skills of asked students. \\
Abstrak \\
\hline Tujuan penelitian ini adalah untuk melihat keefektifan antara \\
layanan informasi dengan menggunakan pendekatan saintifik dan \\
menggunakan metode ceramah untuk meningkatkan keterampilan \\
bertanya siswa. Jenis penelitian ini adalah Quasi Experiment \\
dengan rancangan Pretest-Posttest Control Group Design. Populasi \\
penelitian adalah siswa Madrasah Aliyah Aisyiah Binjai dan SMA \\
Muhammadiyah Binjai, subjek dipilih menggunakan teknik \\
Purposive Sampling. Instrumen penelitian menggunakan kuesioner. \\
Data dianalisis dengan menggunakan Wilcoxon Signed Ranks Test \\
dan Kolmogorov-Smirnov Two Independent Sampel dengan \\
bantuan SPSS versi 20.0. Berdasarkan temuan , layanan informasi \\
dengan pendekatan saintifik lebih efektif untuk meningkatkan \\
keterampilan bertanya siswa.
\end{tabular}

\section{Citation Info}

Siregar, I.K. (2018). Efektivitas Layanan Informasi Menggunakan Pendekatan Saintifik Untuk Meningkatkan Keterampilan Bertanya Siswa. In Biblio Couns: Jurnal Kajian Konseling dan Pendidikan, 1(03), 97-104. 


\section{PENDAHULUAN}

Bertanya merupakan ucapan verbal yang meminta respon atau jawaban dari seseorang, guru atau antar siswa (Asril, 2010). Hal tersebut tersebut tidak seperti yang diharapkan, berdasarkan hasil penelitian Yusmanah (2012) menunjukkan bahwa keterampilan bertanya siswa dalam pembelajaran Matematika termasuk kategori sangat kurang, hal tersebut dapat dilihat dari 35 orang siswa, yangbertanya dengan mengacungkan tangan hanya 12 orang (34,28\%), yang bertanya dengan tulisan 12 orang (34,28\%), yang bertanya dengan sesama teman 12 orang (34,28\%), yang bertanya antar kelompok 6 orang $(17,14 \%)$, siswa yang berani menjawab pertanyaan 15 orang (42,85\%). Selanjutnya, penelitian Siregar (2011) menunjukkan hasil analisis pengamatan awal sebelum diberikan tindakan terdapat 16 orang $(88,9 \%)$ kurang terampil bertanya, dan 2 orang $(11,1 \%)$ yang cukup terampil. Hal ini berarti, sebelum pembelajaran menggunakan metode tanya jawab siswa masih kurang terampil dalam bertanya.Hasil observasi awal yang dilakukan peneliti di Madrasah Aliyah Aisyiah Kota Binjai pada bulan agustus pada mata pelajaran matematika yang berlangsung selama 2 jam (90 menit), diperoleh gambaran beberapa perilaku tidak produktif yang dilakukan siswa dalam proses pembelajaran seperti; (1) siswa tidak serius dalam mengikuti proses pembelajaran, (2) siswa cenderung pasif saat proses diskusi berlangsung, (3) mengerjakan hal-hal yang tidak berkaitan dengan materi pelajaran yang dibahas seperti mengerjakan tugas mata pelajaran yang lain, (4) beberapa siswa mengantuk dan, (5) bermalas-malasan dan bercerita dengan teman yang lain. Pada saat mengajukan pertanyaan, pertanyaan yang diajukan tidak jelas dan tidak ringkas serta tidak fokus pada pokok bahasan yang sedang dibahas, gugup dalam mengajukan pertanyaan dan pendapat.

Hasil pengadministrasian AUM PTSDL siswa mengalami masalah pada keterampilan belajar. masalah yang ada pada siswa perlu pelayanan bimbingan dan konseling untuk membantu menyelesaikan permasalahan tersebut. Konseling merupakan suatu pelayanan bantuan oleh tenaga profesional kepada seseorang atau sekelompok individu untuk pengembangan kehidupan efektif sehari-hari (KES) dan penanganan kehidupan efektif sehari-hari terganggu (KES-T) dengan fokus pribadi mandiri yang mampu mengendalikan diri melalui berbagai jenis layanan dan kegiatan pendukung dalam proses pembelajaran. Pencapaian tujuan pelayanan konseling diperlukan berbagai jenis layanan dan kegiatan pendukung sehingga siswa mampu berkembang secara optimal dan mandiri dalam aspek pribadi, belajar, sosial, dan karir. Salah satu layanan BK yang dapat dilaksanakan adalah layanan informasi. layanan informasi adalah usaha untuk membekali para siswa dengan pengetahuan tentang data dan fakta dibidang pendidikan sekolah, pekerjaan dan bidang perkembangan pribadi-sosial, agar mereka belajar tentang lingkungan hidupnya, lebih mampu mengatur dan merencanakan kehidupannya sendiri (Winkel \& Hastuti, 2006).Berdasarkan hasil penelitian dan observasi dilapangan hal tersebut menunjukkan bahwa siswa tidak terampil dalam bertanya. Siswa tidak terampil dalam mengajukan pertanyaan dilatarbelakangi oleh kurangnya pengetahuan siswa mengenai langkah-langkah dalam bertanya terutama bagi yang baru belajar bertanya dan sikap ketika bertanya. Rendahnya keterampilan bertanya di dalam kelas hal ini juga dipengaruhi oleh kurangnya pemahaman siswa terhadap materi yang dibahas karena siswa tidak mempersiapkan diri sebelum proses pembelajaran berlangsung.

Pelaksanaan layanan informasi diberikan kepada siswa dapat menggunakan berbagai metode, teknik, dan model pendekatan ataupun strategi yang nantinya dapat mencapai tujuan proses pembelajaran. Salah satu pendekatan yang digunakan dalam penelitian ini adalah pendekatan saintifik (Prayitno, 2012). Keterampilan bertanya merupakan salah satu keterampilan yang cukup penting dalam pembelajaran saintifik. 
Pendekatan saintifik mengacu kepada bertanya (questioning), kegiatan belajarnya adalah mengajukan pertanyaan tentang informasi yang tidak dipahami dari hasil pengamatan atau pertanyaan untuk mendapatkan informasi tambahan tentang hal yang diamati (Hosnan, 2014). Pendekatan saintifik (scientific approach) itu lebih efektif hasilnya dibandingkan dengan pembelajaran tradisional (Daryanto, 2014). Hasil penelitian membuktikan bahwa pada pembelajaran tradisional, retensi informasi dari guru sebesar 10 persen setelah 15 menit dan perolehan pemahaman kontekstual sebesar 25 persen. Pada pembelajaran berbasis pendekatan ilmiah, retensi informasi dari guru sebesar lebih dari 90 persen setelah dua hari dan perolehan pemahaman kontekstual sebesar 50-70 persen. Keterampilan bertanya adalah cara penyampaian suatu pelajaran melalui interaksi dua arah yaitu dari guru kepada siswa dan atau sebaliknya agar diperoleh jawaban kepastian materi melalui jawaban lisan guru atau siswa.Pendekatan saintifik diharapkan mampu meningkatkan keterampilan bertanya dikarenakan dalam proses pembelajarannya siswa dapat mengonstruksi pengetahuan sertaketerampilan melalui fakta-fakta yang ditemukan dalam penyelidikan di lapangan sebagai pembelajaran.

Fenomena dan hasil penelitian tersebutmaka peneliti tertarik untuk melakukan penelitian menggunakan layanan informasi dengan pendekatan saintifik untuk meningkatkan keterampilan bertanya siswa.Tujuan yang hendak dicapai dalam penelitian ini adalah untuk: mengungkapkan hal-hal sebagai berikut: (1) Perbedaan skor keterampilan bertanya siswa padakelompok eksperimen sebelum dan setelah diberikan perlakuan layanan informasi dengan pendekatan saintifik, (2) Perbedaan skor keterampilan bertanya siswa pada kelompok kontrol sebelum dan setelah diberikan perlakuan layanan informasi dengan metode ceramah. (3) Perbedaan skor keterampilan bertanya siswa pada kelompok eksperimen yang diberikan perlakuan layanan informasi menggunakan saintifik dengan kelompok kontrol yang diberikan perlakuan layanan informasi dengan metode ceramah.

\section{METODE}

Jenis penelitian ini adalah kuantitatif dengan pendekatan Quasi Eksperiment melalui rancangan The Non Equivalent Control Group Bentuk dari quasi experiment dalam penelitian ini adalah non equivalent control group design atau non randomized pretest-posttest control group design, desain ini hampir sama dengan pretest-posttest control group design pada true experiment, tetapi pada desain kelompok eksperimen maupun kelompok kontrol tidak dipilih secara purposive. populasi dalam penelitian ini adalah siswa Madrasah Aliyah Aisyiah Binjai dan Sekolah Menengah Atas Muhammadiyah Kota Binjai, karena di sekolah ini terdapat masalah yang akan diteliti oleh peneliti. Alasan peneliti memilih kelas tersebut adalah berdasarkan karakteristik kelas yang sama, indikator yang akan diteliti terwakili, dihimpun dari hasil observasi yang dilakukan oleh peneliti, serta rekomendasi dari Guru BK/Konselor di sekolah tersebut. instrumen penelitian. kemudian dianalisis menggunakan uji Wilcoxon Signed Rank Test dan Kolmogorov Smirnov 2 Independent Samples dengan menggunakan program Statistical Product and service Solution (SPSS) versi 20.00.

\section{HASIL}

\section{Perbedaan Frekuensi Kondisi Keterampilan Bertanya Siswa Kelompok Eksperimen}

Berdasarkan data yang peneliti peroleh, maka dapat dideskripsikan hasil penelitian sebelum dilakukan perlakuan dan sesudah diberikan perlakuan hasil pretest dan posttest yang diperoleh pada kelompok eksperimen sebagai berikut: 
Tabel 1. Hasil Pretest dan Posttest Keterampilan Bertanya Siswa Kelompok Eksperimen

\begin{tabular}{lcccc}
\hline \multirow{2}{*}{ Kategori } & \multicolumn{2}{c}{ PreTest } & \multicolumn{2}{c}{ PostTest } \\
\cline { 2 - 5 } & Frekuensi & $\%$ & Frekuensi & $\%$ \\
\hline Sangat Terampil & 1 & 3,33 & 13 & 43,33 \\
\hline Terampil & 0 & 0 & 15 & 50 \\
\hline Cukup Terampil & 5 & 16,67 & 2 & 6,67 \\
\hline Tidak Terampil & 20 & 67 & 0 & 0 \\
\hline Sangat Tidak Terampil & 4 & 13 & 0 & 0 \\
\hline Jumlah & 30 & 100 & 30 & 100 \\
\hline
\end{tabular}

Berdasarkan tabel di atas, dapat diketahui bahwa terdapat perbedaan keterampilan bertanya siswa pada kelompok eksperimen sebelum dan sesudah mendapat perlakuan layanan informasi menggunakan pendekatan saintifik. Kondisi keterampilan bertanya siswa pada saat pretest berada pada kategori sangat terampil sebanyak 1 orang dengan persentase $16,67 \%$, 20 orang siswa dalam kategori cukup terampil dengan persentase $67 \%$, 4 orang siswa dalam kategori sangat tidak terampil dengan persentase 13. Sesudah diberikan perlakuan terjadi perubahan dapat dilihat dari hasil posttest sebanyak 13 orang siswa berada dalam kategori sangat terampil dengan persentase 43,33\%, 15 orang siswa dalam kategori terampil dengan persentase $50 \%$ dan 2 orang siswa berada dalam kategori sangat cukup terampil dengan persentase $6,67 \%$.Berdasarkan hasil di atas terlihat 30 orang siswa pada kelompok kontrol yang dilibatkan dalam perhitungan, mengalami peningkatan skor dari pretest dan posttest atau mengalami perubahan setelah diberikan layanan informasi tanpa menggunakan pendekatan.

\section{Perbedaan Frekuensi Kondisi Keterampilan Bertanya Siswa Kelompok Kontrol}

Berdasarkan data yang peneliti peroleh, maka dapat dideskripsikan hasil penelitian sebelum dilakukan perlakuan dan sesudah diberikan perlakuan hasil pretest dan posttest yang diperoleh pada kelompok eksperimen sebagai berikut:

Tabel 2. Hasil Pretest dan Posttest Keterampilan Bertanya Siswa Kelompok Kontrol

\begin{tabular}{lcccc}
\hline \multirow{2}{*}{ Kategori } & \multicolumn{2}{c}{ Pretest } & \multicolumn{2}{c}{ Posttest } \\
\cline { 2 - 5 } & Frekuensi & $\%$ & Frekuensi & $\%$ \\
\hline Sangat Terampil & 0 & 0 & 8 & 26,67 \\
\hline Terampil & 0 & 0 & 16 & 53,33 \\
\hline Cukup Terampil & 7 & 23,33 & 6 & 20 \\
\hline Tidak Terampil & 22 & 73,33 & 0 & 0 \\
\hline Sangat Tidak Terampil & 1 & 13 & 0 & 0 \\
\hline Jumlah & 30 & 100 & 30 & 100 \\
\hline
\end{tabular}

Berdasarkan tabel di atas, dapat diketahui bahwa terdapat perbedaan keterampilan bertanya siswa pada kelompok kontrol sebelum dan sesudah mendapat perlakuan layanan informasi tanpa menggunakan pendekatan. Kondisi keterampilan bertanya siswa pada saat pretest berada pada kategori cukup terampil sebanyak 7 orang siswa dengan persentase $23,33 \%$, 22 orang dalam kategori tidak terampil dengan persentase 73,33\%, 1 orang siswa dalam kategori sangat tidak terampil dengan persentase 13. Sesudah diberikan perlakuan terjadi perubahan dapat dilihat dari hasil posttest sebanyak 8 orang siswa berada dalam kategori sangat terampil dengan persentase $26,67 \%, 16$ orang siswa dalam kategori terampil dengan persentase $53,33 \%$.Berdasarkan hasil di atas terlihat 30 orang siswa pada kelompok kontrol yang dilibatkan dalam perhitungan, mengalami peningkatan skor dari pretest dan 
posttest atau mengalami perubahan setelah diberikan layanan informasi tanpa menggunakan pendekatan.

Hasil di atas terlihat 30 orang siswa pada kelompok kontrol yang dilibatkan dalam perhitungan, mengalami peningkatan skor dari pretest dan posttest atau mengalami perubahan setelah diberikan layanan informasi tanpa menggunakan pendekatan.

\section{a. Pengujian Hipotesis Pertama}

Hipotesis pertama yang diajukan dalam penelitian ialah "Terdapat perbedaan yang signifikan antara keterampilan bertanya kelompok eksperimen sebelum dan setelah diberi layanan informasi dengan pendekatan saintifik. Dari hasil tersebut maka Ho ditolak dan $\mathrm{H}_{1}$ diterima. Dengan demikian, maka hipotesis pertama yang diuji dalam penelitian ini dapat diterima, yaitu "Terdapat perbedaan yang positif dan signifikan keterampilan bertanya siswa di kelas pada kelompok eksperimen, sebelum dan setelah diberikan perlakuan layanan informasi menggunakan pendekatan saintifk".

\section{b. Pengujian Hipotesis Kedua}

Hipotesis kedua yang diajukan dalam penelitian ialah "Terdapat perbedaan yang signifikan antara keterampilan bertanya kelompok kontrol sebelum dan setelah diberi layanan informasi manggunakan metode ceramah. Dari hasil tersebut maka Ho ditolak dan $\mathrm{H}_{1}$ diterima. Dengan demikian, maka hipotesis pertama yang diuji dalam penelitian ini dapat diterima, yaitu "Terdapat perbedaan yang positif dan signifikan keterampilan bertanya siswa di kealas pada kelompok kontrol, sebelum dan setelah diberikan perlakuan layanan informasi menggunakan metode ceramah atau tanpa menggunakan pendekatan".

\section{c. Pengujian Hipotesis Ketiga}

Hipotesis ketiga yang diajukan dalam penelitian ialah "Terdapat perbedaan yang signifikan antara keterampilan bertanya kelompok eksperimen yang diberi layanan informasi dengan pendekatan saintifik dengan kelompok kontrol yang diberikan layanan informasi manggunakan metode ceramah.". Untuk menguji hipotesis ketiga ini digunakan teknik Kolmogorov Smirnov 2 Independent Samples dengan menggunakan bantuan SPSS versi 20.0. Dari hasil menunjukkan bahwa Ho ditolak dan $H_{l}$ diterima. Dengan demikian, maka hipotesis ketiga yang diuji dalam penelitian ini dapat diterima, yaitu "Terdapat perbedaan yang signifikan antara keterampilan bertanya kelompok eksperimen yang diberi layanan informasi dengan pendekatan saintifik dengan kelompok kontrol yang diberikan layanan informasi manggunakan metode ceramah".

Pada bagian deskripsi data terlihat rata-rata kelompok eksperimen lebih tinggi dibandingkan kelompok kontrol. Kategori sangat terampil pada kelompok eksperimen mengalami peningkatan nilai rata-rata sebesar 186,47 , sedangkan kelompok kontrol juga mengalami peningkatan dalam kategori sangat terampil juga dengan nilai rata-rata 184,83 . Berdasarkan hasil rata-rata kelompok eksperimen dan kelompok kontrol memiliki selisih sebesar 1,64, dengan adanya hal tersebut maka terdapat perbedaan dari hasil perlakuan kelompok ekperimen yang diberikan layanan informasi menggunakan pendekatan saintifik dan kelompok kontrol yang diberikan layanan informasi menggunakan metode ceramah atau tanpa menggunakan pendekatan. Jadi dapat disimpulkan layanan informasi menggunakan pendekatan saintifik lebih efektif untuk meningkatkan keterampilan bertanya siswa di kelas dibandingkan layanan informasi menggunakan metode ceramah. 


\section{PEMBAHASAN}

Nursalim (dalam Fitriyah 2014:376) mengemukakan bahwa "Layanan informasi adalah layanan bimbingan dan konseling yang memungkinkan siswa menerima dan memahami berbagai jenis informasi, yang dapat dipergunakan sebagai bahan pertimbangan dan pengambilan keputusan untuk kepentingan siswa". Prayitno (2012:50) mengemukakan bahwa "Tujuan layanan informasi adalah agar seseorang menguasai berbagai informasi yang diperlukan dalam kehidupannya untuk membantu perkembangannya sehingga terwujud kehidupan efektif sehari-hari (KES)". Selanjutnya, Ramadhani, E \& Putri, R.D (2018) mengungkapkan bahwa layanan informasi adalah layanan yang memberikan suatu informasi untuk membantu siswa/ klien mempertimbangkan dalam pengambilan keputusan. Layanan informasi diselenggarakan oleh konselor yang diikuti oleh siswa yang menjadi subjek penelitian.Layanan informasi secara intensif dan terprogram memilih topik-topik umum yang menarik, hangat, teraktual, sesuai dengan kebutuhan dan bermanfaat untuk siswa.Melalui layanan informasi yang telah terprogram siswa memperoleh berbagai keterampilan dari setiap topik yang telah dibahas. Dengan demikian, siswa memiliki pandangan serta sikap untuk mengaplikasikan keterampilan bertanya dalam proses pembelajaran, sehingga dalam kegiatan di kelas siswa menjadi aktif dan kreatif.

Keterampilan bertanya perlu dikembangkan karena partisipasi siswa dalam mengajukan pertanyaan selama proses pembelajaran menunjukkan ketercapaian siswa dalam menerima, maupun memahami materi pelajaran. Karena bagi siswa, pertanyaan yang diajukan dapat mengarahkan mereka membangun pengetahuan, mengaktifkan diskusi dalam meningkatkan kualitas interaksi pembelajaran baik dengan guru, maupun siswa yang lain, membantu siswa mengevaluasi pemahaman, serta meningkatkan minat belajar dengan membangkitkan rasa ingin tahu.

\section{KESIMPULAN}

Peneliti menyimpulkan bahwa layanan informasi merupakan layanan yang memungkinkan siswa dan pihak-pihak lain dapat memberikan pengaruh besar dalam menerima, memahami, dan penguasaan informasi. Sehingga dapat mengambil keputusan, mengarahkan diri untuk kegiatan-kegiatan yang sesuai dengan keputusan yang diambil, dan akhirnya siswa dapat mengaktualisasikan diri secara terintegrasi dalam proses pembelajaran di dalam kelas. 


\section{REFERENSI}

Daryanto. (2014). Pendekatan Pembelajaran Saintifik Kurikulum 2013. Yogyakarta: Gava Media.

Fauziah. (2013). Pembelajaran Saintifik Elektronika Dasar Berorientasi Pembelajaran Berbasis Masalah. Journal Invotec, 9 (2): 165-178.

Hosnan. (2014). Pendekatan Saintifik dan Kontekstual dalam Pembelajaran Abad 21. Jakarta: Ghalia Indonesia.

Prayitno \& Amti, E. (2012). Dasar-dasar Bimbingan dan Konseling. Jakarta: Rineka Cipta.

Ramadhani, E., \& Putri, R.D. (2018). Implementasi Pendekatan Discovery Learning dalam Layanan Informasi Format Klasikal. Jurnal Wahana Konseling. 1(02). 